\title{
9. RE-INFUSING ADULT EDUCATION WITH A CRITICAL FEMINIST FRAMEWORK
}

\author{
Inspiration from Mary Parker Follett
}

This chapter argues the necessity to create space for a critical feminist perspective not only for the good of adult education but for the good of the global community as well. Feminist theorizing, especially around issues of power and collective change, can contribute greatly to our creation of this space, especially to understand women's learning and activism within the larger international sphere and contribute to the global project of active citizenship. Such theorizing, inspired by giants such as hooks (2000), needs to be reclaimed as a part of the adult education toolbox so our conversations and dialogue are always grounded and challenged by ideas, and complex and deep thinking. This must be accompanied by a strong adult education focus built on theory, practice, activism, and community, highlighting teaching practices and contexts where adult educators themselves learn informally and nonformally.

As established earlier (English \& Irving, 2015), there is a continuing need to draw from and further contribute to a literature on women and learning, especially from a critical, political and engaged perspective, namely feminism. Issues of women, learning and resistance continue to matter, and despite conservative rhetoric (e.g., Sandberg, 2013), a deliberate focus on women, gender and learning, as well as a more nuanced view of power, is required to address the recurring myth that adult education has moved beyond the need for attention to women. In response, this chapter argues for the importance of a feminist analysis of the nexus of women, power and possibility drawing on a major theorist of power - Mary Parker Follett (1868-1933), a community-based educator and lecturer in the early 20th century (Follett, 1924, 1941). Follett's stress on collective action and the co-creation of power undergirds her understanding of democracy as an ongoing project and of power as an integral part of human relations.

\section{FEMINISM AND ADULT EDUCATION}

First, though, a word about the general relevance of feminism to the overall adult education project. Clearly, not all adult educators are drawn to an emphasis on radical social change that feminist adult educators like Butterwick, Taber, and 
Clover have led and have written about (see English \& Irving, 2015). In its stead, humanism, long the mainstay of our field in education contexts, has encouraged a personal and individual focus; while in certain respects laudable, it has sometimes championed a stress on safe and secure teaching and learning practices and efforts at self-development and actualization, at the expense of attention to criticality. Witness the emphasis on personal transformative learning in North American contexts to the degree that there are entire journals and annual conferences dedicated exclusively to this stream of research. Yet, it is feminist theorizing and more particularly social transformative efforts that have given support to many of these humanistic efforts, to the point where inclusive education, a focus on the marginalized in learning, and support for personal transformation and creativity have become mainstream practices, without due credit to or positioning within the feminist pedagogy that launched it (Brookfield, 2010). Adult education has been slow to recognize the central and vital role that theoretical and practical efforts of feminism have played in bringing our ideas into the mainstream (English \& Irving, 2015).

A contributing factor to the backlash against feminism and to a certain reticence in using the term is the mistaken belief that equality is now the norm and that women have attained full and equal rights (see English \& Irving, 2015). Western media is preoccupied with portraying women through self-focused practices such as yoga, relaxation, and self-reflexivity (sans the critical) and of highlighting individual women who have reached the top rung of corporations. Our popular press is so besieged by discussions of women attaining high-ranking corporate status while struggling to balance work and family life that one can be forgiven for thinking that it is 1950 and not the 21 st century. The danger of such thinking, of course, is that it is "nostalgia without memory" (p. 30) to use anthropologist Arjun Appadurai's (1996) phrase. We can easily forget that we are global citizens and that our struggles for equality are not over; indeed, we can also forget that there was a struggle and it is ongoing. Western privileging of the "self" moves the focus from the collective and social approach of feminism and its political approach of addressing discriminatory practices and systems, which diminish the whole. A feminist perspective sees adult education in broad terms and is willing to continue contributing to an understanding of education, learning and change.

Despite the lapses in current educational thinking, scholarship published sporadically in the past few decades has been helpful in keeping a collective focus on feminism and learning. When activists Walters and Manicom (1996) issued their edited volume Gender in Popular Education: Methods for Empowerment, they were able to highlight feminist-informed popular education methods used in community contexts around the world.

From a complementary sociological perspective, Miles' (2013) edited volume, Women in a Globalizing World, analyzed complex development issues for women; like Manicom and Walters (2012), Miles' contributors highlighted the diversity of the spaces claimed by women to promote learning and action, especially in community development contexts. Contributors to Taber's (2015) special issue of 
the Canadian Journal for the Study of Adult Education also emphasized the links between feminism and the community. In Ireland, scholars such as O'Grady (2018) continued an interest in how women have been working together in the community for collective societal transformation. Yet, much needs to be done to maintain this focus and to expand its reach. One possible solution is to look back to our forebears such as Mary Parker Follett for insight.

\section{WOMEN, GLOBAL CHALLENGES AND DIFFERENT VERSIONS OF FEMINISM}

For all these signs of hope, the early 21 st century has nevertheless been challenging for those pursuing feminist approaches to adult education. Sociologists Eichler et al. (2010) have made this point as have English and Irving (2015). Eichler (2005) herself pushed back at increasing corporatization in adult education by studying women's housework as the site of valuable informal learning, calling for even more attention to the everyday nature of women's learning. Despite important scholarship like hers, feminist adult education concerns are not at the forefront of adult education scholarship. For instance, in 2018, the editors of the decennial American Handbook of Adult and Continuing Education replaced the chapter on women and feminist analysis with a chapter on LBGTQ issues, which while broader and presumably more inclusive, takes the focus off women as a political category (personal correspondence with the author). Such a stance is troubling since the reality of women's position globally remains very unequal. For instance, UNESCO's (2016) 3rd Global Report on Adult Learning and Education observed that "The majority of those excluded from school are girls, with $9.7 \%$ of the world's girls out of school, compared to $8.3 \%$ of boys. Likewise, the majority (63\%) of adults with low literacy skills are women" (p. 4). With such a basic issue as women's literacy on the table, the stakes continue to be high. Women and girls continue to be disproportionately affected by issues such as literacy, climate change and even disability (UNESCO-UIS, 2018). Stromquist (2013) has shown that even UNESCO has fallen short of its commitments to women. Its global conference, CONFINTEA VI, in Belém, Brazil in 2009, did not focus any of its recommendations on women, save for indirectly referring to it in one place as "participation, inclusion and equity" (p. 32). Clearly, the need to focus on collective change and action for women needs global as well as local impetus and support.

An immediate challenge is attracting young women to feminism and its concerns. Susan Bracken (2008) notes that one of the most difficult aspects of her teaching is naming it as feminist and of having her students engage with the term; she reports that some of her undergraduate students find the term problematic and dated, and associate it exclusively with radical protests. Bracken struggles with whether to call the work feminist and whether to insist with advancing her feminist theory and pedagogy in a higher education context which may for some students seem to be disconnected from oppression, poverty and literacy issues and which may make the political goals of feminism seem foreign. It may also be true that the neoliberal and 
right-wing agenda of "learning for earning" pervades higher education, making it difficult for debt-saddled students to attend to critical issues that seemingly do not involve them. Education becomes the commodity of the knowledge economy where the market dictates what learning is valuable or saleable.

Arguably, second wave feminist language and arguments, which grounded writers such as Miles (2013) and Manicom and Walters (2012), are in need of redressing and re-invigorating. In part, this is an acknowledgment that younger feminists, especially those in adult education, did not live through the 1970s, and have divergent interests.

\section{LOOKING BACKWARDS; LOOKING FORWARDS}

With this current context of scholarship and practice as a prelude, I propose looking backwards to the sources available pre-second wave feminism, as a way to find inspiration for this decade in adult education. Though such an intellectual approach may initially seem somewhat counter-intuitive, it may provide resources that can help us reengage with feminism, especially with its theorizing about power, the key to understanding major education and learning dilemmas, especially as they affect life in the community. A key feminist source that has been overlooked, especially in North America, is Mary Parker Follett, who has been claimed by scholars in the management sciences, despite the fact that much of her early working career was in community organizing and social change in inner city Boston. Interestingly, adult educators Preskill and Brookfield (2009) drew on her ideas of power in their book on theories of leadership and social change, but they have yet to look at her overall contributions to adult education and learning. Somehow, Follett has escaped the eye of mainstream adult education practices and thinking, at least in North America, a situation that needs addressing, especially given her insights about power. It is also fair to say that our field needs to mine the insights of its own people for its own theoretical purposes.

Feminist theorizing (and the absence thereof) can contribute greatly to our understanding of women's learning and activism within the sphere. In focusing on the practice of the adult educator teaching and learning such as Follett did in the inner city, there is a possibility of a deeper examination of Eyben's (2014) tension of "working within existing paradigms or changing them" (p. 160), in order to present possibilities for bona fide inclusion and participation in learning and action. Feminist learning and citizen's learning are intertwined: both involve the ways people come together to create a collective understanding of social conditions in order to claim and open up spaces for participation and to change power relations.

Feminist theorizing and feminist adult education is, of course, not distinct from the adult education field. Its concerns ought to be those of the field in general dealing with difference, marginalization, participatory engagement, and progress. Feminist adult education would be richer for looking back to the insights of women such as Follett. In the current attempt to unite with other causes, to find multiple heuristic lenses, to struggle for the rights of learners, we have seemingly foregone 
special attention to women; such de-politicization means that women's needs and causes are increasingly hidden. In focusing on women as a distinct political category and group, and using a politically infused feminism as a critical lens, we can find spaces of hope.

Follett's theory, especially that developed in her book Creative Experience (1924) starts from her contradictory experience of being born into an elite Quaker family in Massachusetts, and yet dedicating her early years to building and strengthening community centres in the troubled Roxbury neighborhood of inner city Boston. An intellectual, lesbian and graduate of what is now the prestigious Radcliffe College, the sister school of Harvard University which did not then admit women, Follett knew firsthand the challenges of inequality in society. Although she never held a university position, she ably used her community experience and her many invitations to address groups, to deepen public awareness and to record her own insights and theories of power. That her ideas have not been fully unpacked for adult education, and for feminism in particular, is a shame. In her lifetime, she gave public lectures and wrote extensively; her publications include The Speaker of the House of Representatives (1896); The New State: Group Organization the Solution of Popular Government (1918); Dynamic Administration: The Collected Papers of Mary Parker Follett (1941); The Illusion of Final Authority: Freedom and CoOrdination: Lectures in Business Organization (1954).

Mining afresh the writing of Mary Parker Follett may indeed provide new insight for adult education, which is also interested in educating and leading organizations. Follett's theory addresses the community - politics, school, neighborhood - which are the central sites of adult education practice. One of her seemingly benign insights is that there is need for people in the community to talk to each other, to break down barriers, in order to address collective concerns and to negotiate conflict (Follett, 1941). At heart, she believed in the democratic process, whereby the people most affected by particular problems need to work together to figure out their own issues and solutions. Key in her practice and theorizing was her refusal to defer to experts and her insistence on the need for engagement in collective work and decision making to effect change. For example, she thought that the day school buildings ought to be used as neighborhood centers where people in the community could come together face to face to plan and move forward, a fairly basic idea that is still meeting resistance today. In her willingness to engage the other, to put forth realizable solutions, and to prioritize participatory processes, Follett's ideas unfolded in a similar way to those of feminism which also privileges collective struggle for social change. Although one might argue that she herself did not politicize her work or thinking fully, we might also say that for her time she was both ingenious and effective; as a result of her steady and committed leadership, the community center idea took hold in Boston and surrounding areas, as well as across the United States (Tonn, 2013). She chose strategic thinking as her modus operandi and the everyday world as her locus, allowing her to reach ordinary people and to create a change in thinking about women, collective action and power. Her approach was to be 
directly involved in the mundane world of community centers, literally bringing groups together to talk and plan about issues that affected them. She recognized that being with vulnerable populations in the inner city and helping them find collective solutions to their problems was important.

Perhaps best known of Follett's ideas on power, and perhaps the most misused, was the concept of "power with", not "power over" (Follett, 1941; Mott, 2015). A practicing Quaker, Follett wanted to look at how to work with strengths and difference to enhance society and promote peace, despite the multiple social and economic barriers one encountered. In her book Creative Experience (1924), she outlined her aspirations of "power with" practice to reach a point in our communities and workplaces where we are actively engaged in creating decisions and enacting plans to move forward. For instance, in her inner city work, she saw great value in sitting opposing sides down together to dialogue about controversial issues. Her books drew on her community organizing experience and showed how dialogue with people who are different can help create new awareness and possibility. Despite the obvious critique that true equality can be elusive, her ideas are refreshing in that they came from the community and were part of an ongoing community-based effort to work together for change (Preskill \& Brookfield, 2009). Significantly, she was also not averse to using so-called power or authority positions as she served on committees to create a minimum wage for workers and she headed up a national community center organization. As a participant in these groups, she was able to infuse her ideas and strengthen civil life.

Though her work experience was limited to the community, Follett readily applied her theories and practices to business and management. She (1924) explained her theory saying that power:

is the problem of industry, of politics, of international affairs. But our task is to not to learn where to place power; it is how to develop power. We frequently hear nowadays of 'transferring power' as the panacea for all our ills ... but the transference of power has been the whole course of history - power passing to priests, or king or barons, to council or soviet. Are we satisfied to continue this puss-in-the-corner game? ... Genuine power can only be grown. (1924, pp. xii-xiii)

Her idea was to avoid a top down approach and to find ways for workers to come together to create new solutions. As a strategic thinker, she identified power as the central social problem and she had unique ways of thinking about it - she saw it as something to be developed with others, not over or against them. In her words,

... genuine power is capacity .... The main problem of the workers ... is how much power they can themselves grow. The matter of workers' control which is often thought of as a matter of how much managers will be willing to give up, is really as much a matter for the workers, of how much they will be able to assume. (Follett, 1941, p. 109) 
Follett (1941) felt that "integration" (p. 45) or the meeting of all sides in labor disputes, community debates, and personal interactions was the only way to create power. She saw the other choices such as domination and compromise to be lesser alternatives and to fall short in the long run.

What happens to a man, in a man, when an order is given in a disagreeable manner by a foreman, head of department, his immediate superior in store, bank or factory? The man addressed feels that his self-respect is attacked, that one of his most inner sanctuaries is invaded. He loses his temper or becomes sullen or is on the defensive; he begins thinking of his 'rights' - a fatal attitude for any of us. (cited in Tonn, 2013, p. 400)

In Follett's eyes, power arises, so our educational and organizing job is to grow this power: to take or seize the moment to create a new social order. This concept anticipates later thinking on power such as that of Foucault (English \& Mayo, 2012). Follett complemented her primary ideas on power with her understanding of "circular response" which acknowledges the ways in which one person's ideas interact with and influence the next, how a group's actions inform and interact with each other to create new possibilities and formulations (see Preskill \& Brookfield, 2009). The "power" embedded in this formulation helps to advance our understanding of the collective change process and helps debunk narcissistic individualism that prevents change. Embedded in the theory of circular response is the recognition of the transformative aspects of conflict and the creative tension that is often the bedrock of change and growth, a key idea for feminist adult education. Sadly, Follett's theory of power has sometimes been reduced to the win-win philosophy of business practice, which is a very minimalist reading of her thinking. For her, community organizing was deeply democratic and sometimes painful work and was not done in a quest for increased profit. Rather, its end goal was collective resistance and change. This clearly is a feminist idea that sits well with the ordinary educational tasks of the adult educator engaged in meaningful community work. We could say the same of adult education work in higher education contexts, global initiatives, community development and non-profit leadership.

Follett's ideas are helpful to adult educators interested in feminism as they parallel feminism's struggle to create equality and to have democratic principles at the core. Her struggles as an intellectual woman in a patriarchal society infuse her work and ideas, challenging us to bring energy to our collective struggles. She was not known as an activist, yet her very work, ideas and forward thinking on power and collectivity were indeed oriented to social transformation. In many ways, Follett's seemingly basic ideas on community and power are brilliant in their simplicity. These ideas have substance in that they acknowledge the complexity of everyday life and promote a sense of self as well as community. They reflect a deep sense of meaning and orientation to transformation, key feminist ideas. Yet, despite all her writing, one wishes she had spent more time in theorizing power and applying it to 
multiple contexts; the fact that she did not have an academic position likely limited her time for writing and developing these ideas.

While Follett was not writing only about women, her own lived experience of marginalization as a gay woman working outside the academy with vulnerable populations rings true for feminism which privileges those disproportionately affected by problematic social, economic and cultural issues. We can only speculate on how her feminism would have been enacted in the public sphere if she were living now. The only alternative is to mine the ideas she has left us.

The precarious nature of women's lives globally forces adult educators to keep their focus on women. In the attempts of adult educators to focus on multiple identity issues, and to support gender mainstreaming we have obscured women's issues and theories of power. Jenevieve Mannell (2012) pointed out that after Beijing World Conference in 1995, there was a deliberate effort to mainstream women's issues (and not separate them out), which often led to the inclusion of women becoming little more than a technical task - one more box on a checklist to be filled in to show that one was diverse and inclusive. Inspired by Follett, we might do better to confront the issues and work with them directly as she advocated and practiced. Rather than shy away from controversy, she engaged it and worked through the differences.

Meanwhile, we can see that the global issues before us are increasing complex for women. The issues played out in the American election in 2016 and those of the 2018 \#MeToo Movement are a not so subtle reminder that feminist issues are still at the forefront of the public agenda. Mary Parker Follett's insights can inform a feminism of co-created power, inclusion, and community and help to bring adult education into the world as a key hermeneutical lens from which to view many crucial aspects of our collective life. Our challenge is not to see it as an aside to adult education but as a key part of our toolbox; similarly, feminism depends on education. bell hooks (2000) notably said, "Most people have no understanding of the myriad ways feminism has positively changed all our lives. Sharing feminist thought and practice sustains the feminist movement. Feminist knowledge is for everybody" (p. 24).

\section{REFERENCES}

Appadurai, A. (1996). Modernity at large: Cultural dimensions of globalisation. Minneapolis, MN: University of Minnesota Press.

Bracken, S. (2008). Submerged feminism(s)? In J. K.Allen, D. R. Dean, \& S. J. Bracken (Eds.), Most college students are women: Implications for teaching, learning and policy (pp. 159-172). Stirling, VA: Stylus.

Brookfield, S. D. (2010). Theoretical frameworks for understanding the field. In C. Kasworm, A. D. Rose, \& J. M. Ross-Gordon (Eds.), Handbook of adult and continuing education (2010 ed., pp. 71-81). Thousand Oaks, CA: Sage.

Eichler, M. (2005). The other half (or more) of the story: Unpaid household and care work and lifelong learning. In N. Bascia, A. Cumming, A. Datnow, K. Leithwood, \& D. Livingstone (Eds.), International handbook of educational policy (Vol. 13, pp. 1023-1042). Dordrecht: Springer.

Eichler, M., Albanese, P., Ferguson, S., Hyndman, N., Liu, L. W., \& Matthews, A. (2010). More than it seems: Household work and lifelong learning. Toronto: Women's Press. 


\section{RE-INFUSING ADULT EDUCATION WITH A CRITICAL FEMINIST FRAMEWORK}

English, L. M., \& Irving, C. (2015). Feminism in community: Adult education for transformation. Rotterdam, The Netherlands: Sense Publishers.

English, L. M., \& Mayo, P. (2012). Learning with adults: A critical pedagogical introduction. Rotterdam, The Netherlands: Sense Publishers.

Eyben, R. (2014). Subversively accommodating: Feminist bureaucrats and gender mainstreaming. In A. Cornwall \& J. Edwards (Eds.), Feminisms, empowerment and development: Changing women's lives (pp. 159-174). London: Zed Books.

Follett, M. P. (1896). The speaker of the house of representatives. New York, NY: Longmans, Green.

Follett, M. P. (1918). The new state: Group organization, the solution of popular government. University Park, PA: Pennsylvania State University Press.

Follett, M. P. (1924). Creative experience. New York, NY: Peter Smith.

Follett, M. P. (1941). Dynamic administration: The collected papers of Mary Parker Follett (H. C. Metcalf \& L. Urwick, Eds.). New York, NY \& London: Harper \& Brothers.

Follett, M. P. (1954). The illusion of final authority: Authority must be functional and functional authority carries with it functional responsibility. Washington, DC: U.S. Bureau of Public Assistance.

hooks, b. (2000). Feminism is for everybody. New York, NY: South End Press.

Manicom, L., \& Walters, S. (2012). Feminist popular education in transnational debates. Building pedagogies of possibility. New York, NY: Palgrave MacMillan.

Mannell, J. (2012). 'It's just been such a horrible experience.' Perceptions of gender mainstreaming by practitioners in South African organisations. Gender \& Development, 20(3), 423-434. doi:10.1080/ 13552074.2012 .731753

Miles, A. (Ed.). (2013). Women in a globalizing world: Transforming equality, development, diversity and peace. Toronto: Inanna.

Mott, V. (2015). Mary Parker Follett: A paradox of adult learner and educator. In S. Imel \& G. Bersch (Eds.), No small lives: Handbook of North American early women adult educators, 1925-1950 (pp. 125-139). Charlotte, NC: Information Age Publishers.

O'Grady, M. (2018). An institutional ethnography of a feminist organization: A study of community education in Ireland. European Journal for Research on the Education and Learning of Adults, 9(1), 29-44. doi:10.3384/rela.2000-7426.rela9104

Preskill, S., \& Brookfield, S. (2009). Learning as a way of leading: Lessons from the struggle for social justice. San Francisco, CA: Jossey-Bass.

Sandberg, S. (2013). Lean in: Women, work, and the will to lead. New York, NY: Knopf.

Stromquist, N. P. (2013). Adult education of women for social transformation: Reviving the promise, continuing the struggle (New Directions for Adult and Continuing Education, No. 138) (pp. 29-38). San Francisco, CA: Jossey-Bass. doi:10.1002/ace.20051

Taber, N. (Ed.). (2015). A critical engagement with the current place of feminism in Canadian adult education [Special issue]. Canadian Journal for the Study of Adult Education, 27(2). Retrieved from http://journals.msvu.ca/index.php/cjsae

Tonn, J. (2013). Mary P. Follett: Creating democracy, transforming management. New Haven, CT: Yale University Press.

UNESCO Institute for Lifelong Learning. (2016). 3rd Global report card on adult learning and education: Key messages and executive summary. Hamburg: Author. Retrieved from http://unesdoc.unesco.org/ images/0024/002459/245917e.pdf

UNESCO-UIS. (2018). Education and disability: Analysis of data from 49 countries (Information paper No. 49). Retrieved from http://uis.unesco.org/en/news/education-and-disability-analysis-data-49countries

Walters, S., \& Manicom, L. (Eds.). (1996). Gender in popular education: Methods for empowerment (pp. 1-22). London: Zed Books. 